\title{
Constitutional Values, Therapeutic Jurisprudence and Legal Education in South Africa: Shaping our Legal Order
}

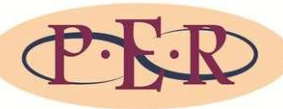

Author

Elmarie Fourie

\section{Affiliation}

University of Johannesburg South Africa

Email esfourie@uj.ac.za

Date published 29 April 2016

Editor Prof C Rautenbach

How to cite this article

Fourie E "Constitutional Values, Therapeutic Jurisprudence and Legal Education in South Africa: Shaping our Legal Order" PER/ PELJ 2016(19) - DOI

http://dx.doi.org/10.17159/1727 3781/2016/v19i0a732

\section{Copyright}

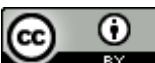

This work is licensed under a Creative Commons Attribution 4.0 International License.

\section{DOI}

http://dx.doi.org/10.17159/17273781/2016/v19i0a732

\begin{abstract}
Law schools have a responsibility to remind law students that by studying law they have the power to transform thoughts, policies and lives, and that practising law is not just about financial rewards, but that its greatest reward is contributing to the betterment of society and ultimately to social change. The values and philosophies that law lecturers instil in law students can contribute to the legal order of the future; a legal order that supports a transformative South Africa. A need exists to bring legal education closer to the values enshrined in our Constitution. In addition to an extensive knowledge of legal principles, critical thinking and research skills, law students should critically engage with our constitutional values. The question remains: How do we transform legal education in South Africa? How do we change the way we teach law students? The introduction of concepts such as therapeutic jurisprudence enhanced by our constitutional values will ensure that we deliver graduates that display a commitment to our constitutional vales and an ability to engage critically with these values. It is important to establish a professional legal identity amongst students from their first year as this will assist in the development of a well-rounded graduate that can contribute to the legal order of the future. Letter writing and drafting skills, the value of plain language, moot court activities, alternative dispute resolution and clinical legal education provide opportunities to integrate valuable therapeutic jurisprudence principles into the curriculum and can allow students to critically engage with our constitutional values. By embodying these values they can improve the legal system, shape our legal order and promote progress toward an equal and free democratic society as envisaged by the Constitution.
\end{abstract}

\section{Keywords}

Therapeutic; jurisprudence; legal; education, transformative constitutionalism; preventative; lawyering; constitutional; values; professional legal identity. 
A truly transformative South Africa requires a new approach that places the Constitutional dream at the very heart of legal education. It requires that we regard law as part of the social fabric and teach law students to see it as such. They should see law for what it is, as an instrument that was used to oppress in the past, but that has that immense power and capacity to transform our society. Much has been done to bring legal education in line with these ideals. ${ }^{1}$

\section{Introduction}

Law schools have a responsibility to remind law students that by studying law they have the power to transform thoughts, policies and lives, and that practising law is not just about financial rewards, but that its greatest reward is contributing to the betterment of society and ultimately to social change. The values and philosophies that law lecturers instil in law students can contribute to the legal order of the future; a legal order that supports a transformative South Africa. ${ }^{2}$ Quinot ${ }^{3}$ refers to fundamental changes in teaching law, and argues that a transformative legal education framework is a crucial element of transformative constitutionalism in South Africa. $^{4}$

A need exists to bring legal education closer to the values enshrined in our Constitution. ${ }^{5}$ In addition to an extensive knowledge of legal principles, critical thinking and research skills, law students should critically engage with our constitutional values. ${ }^{6}$ Students should have a knowledge and appreciation of the values in the Constitution. Judge Davies refers to a constitution-free zone that exists where the Constitution is not integrated

* Elmarie Fourie. BProc ADL LLM (University of Johannesburg). Senior Lecturer, Department of Procedural Law, University of Johannesburg. Email:esfourie@uj.ac.za.

Langa 2006 Stell LR 356.

Langa 2006 Stell LR 356.

Quinot 2012 SALJ 411. Quinot argues that a transformative legal education calls for a fundamental shift from legal reasoning to substantive reasoning under a transformative constitution. He refers to a shift towards a constructivist studentcentered teaching model.

$4 \quad$ Klare 1998 SAJHR 150. Klare defines transformative constitutionalism as a longterm project of constitutional enactment, interpretation and enforcement committed to transforming the country's political and social institutions and power relationships in a democratic, participatory and egalitarian direction. Justice Langa points out that a commitment to transform our society lies at the heart of our new constitutional order. He refers to the epilogue to the constitution, describing it as a bridge between the past of a deeply divided society and a future founded on our constitutional values. Langa 2006 Stell LR 352.

5 Klare 1998 SAJHR 151. Greenbaum states that it is imperative to align legal education with the project of transformative constitutionalism. Greenbaum "Revisioning Legal Education" 1.

$6 \quad$ Langa 2006 Stell LR 356. 
into key areas of the law. ${ }^{7}$ He argues that the Constitution must be integrated into any holistic analysis in student textbooks, and a failure to educate students to meet the challenges posed by the developmental clauses in our Constitution will slow the process of transforming our society. 8

A well-rounded graduate should display a commitment to constitutional values and principles and have the ability to apply these values and principles when entering the profession. The question remains: How do we transform legal education in South Africa? How do we change the way we teach law students ${ }^{9}$ In what follows I provide practical examples of transforming legal education through the incorporation of therapeutic jurisprudence principles and constitutional values in skills modules and ultimately a compulsory law clinic module presented at the University of Johannesburg. I argue that the introduction of concepts such as therapeutic jurisprudence enhanced by constitutional values such as human dignity, equality, freedom and ubuntu ${ }^{10}$ into the mainstream curriculum will enable law schools to deliver therapeutically orientated lawyers, with a commitment to our constitutional values and an ability to engage critically with these values. This approach ensures an engagement with a legal method of teaching that can meet the transformative challenges facing legal education in a democratic South Africa.

In addition to the above I shall focus on the engagement of law students with the concept of a professional legal identity where students will work towards a career goal that has meaning and purpose. ${ }^{11}$ I shall illustrate how this approach will enhance the quality and integrity of our lawyers in line with our transformative Constitution and can contribute to the process of transforming legal education.

\footnotetext{
Davies 2015 Acta Juridica 182.

Davies 2015 Acta Juridica 182.

Justice Langa states that we can no longer teach lawyers of tomorrow that they must blindly accept legal principles because of authority. They must be able to engage with the values of the Constitution of the Republic of South Africa, 1996 and implement these values in their practice. He points out that this change includes a change in mind-set (Langa 2006 Stell LR 356).

10 In S v Makwanyane 19952 SACR 1 (CC) paras 237, 263, Madala J states that the concept ubuntu carries in it the ideas of humaneness, social justice and fairness. In the same judgment Mohamed $\mathrm{J}$ stated that ubuntu expresses the ethos of an instinctive capacity for and enjoyment of love towards fellow men and women and the fulfilment involved in recognizing their innate humanity. $\mathrm{He}$ also refers to the reciprocity that this generates in interaction within the collective community.

11 Field, Duffy and Huggins 2013 FYHE 15.
} 


\section{Conceptual framework}

It is important to provide a conceptual framework for the key concepts to highlight the importance of different approaches and the compatibility and integration of the concepts into the law curriculum.

The concept therapeutic jurisprudence is explained on the website of the International Network on Therapeutic Jurisprudence as follows: ${ }^{12}$

[T]herapeutic jurisprudence concentrates on the law's impact on emotional life and psychological wellbeing. It is a perspective that regards the law (rules of law, legal procedures, and roles of legal actors) itself as a social force that often produces therapeutic or anti-therapeutic consequences. It does not suggest that therapeutic concerns are more important than other consequences or factors, but it does suggest that the law's role as a potential therapeutic agent should be recognised and systematically studied.

A therapeutic jurisprudence approach is an interdisciplinary approach to studying law's impact on emotional life and focusses on the therapeutic and anti-therapeutic consequences that can flow from legal rules, legal procedure and the different roles of legal actors. ${ }^{13}$ Initially the focus of therapeutic jurisprudence was on mental health, but the focus now includes the well-being of all citizens. ${ }^{14}$ This shift in focus supports humaneness, social justice and fairness, concepts that are encompassed by the value of ubuntu. ${ }^{15}$ This approach recognises the social responsibilities of the law and that the legal system must also be seen as a core component of the social fabric of society. ${ }^{16}$ The approach appears to be compatible with the statement of Mohamed $J$ in $S v$ Makwanyane, ${ }^{17}$ that ubuntu expresses the ethos of an instinctive capacity for, and enjoyment of love towards fellow men and women and the fulfilment involved in recognising their innate humanity. ${ }^{18}$ Although the notion of therapeutic jurisprudence is still fairly unexplored in South Africa, the following examples highlight the characteristics of this approach: ${ }^{19}$ the

12 Wexler 1999 http://www.law.arizona.edu/depts/upr-intj/intj-welcome.html. This concept was first introduced in the 1990's, and although its foundation is in mental health, its scope has widened to other branches of the law, such as employment law, disability law and criminal law.

13 Stolle and Wexler 1997 Preventive L Rep 4.

14 Stolle and Wexler 1997 Preventive L Rep 7.

15 See S v Makwanyane 19952 SACR 1 (CC) paras 237, 263 and fn 10 above.

16 Davies 2015 Acta Juridica 175.

17 S v Makwanyane 19952 SACR 1 (CC) paras 237, 263.

18 See S v Makwanyane 19952 SACR 1 (CC) paras 237, 263.

19 Rautenbach 2005 SAJHR 323. 
appointment of assessors during the trial; ${ }^{20}$ correctional supervision; $;{ }^{21}$ and the use of special courts, such as family courts and customary courts. ${ }^{22}$

Preventative law has been described as: "a branch of the law that endeavours to minimize the risk of litigation or to secure more certainty as to legal rights and duties". ${ }^{23}$

Preventative lawyering ensures a proactive approach to lawyering and a focus on planning for and avoiding future disputes, and securing the client's legal rights and opportunities. ${ }^{24}$ The lawyer here fulfills the role of planner, counsellor and negotiator. ${ }^{25}$ Clinical education provides various opportunities to promote preventative lawyering through various community outreach programmes. ${ }^{26}$

Students can be introduced to these concepts when they are required to read interdisciplinary therapeutic jurisprudence and preventative lawyering scholarship as compulsory reading materials. ${ }^{27}$ Introducing these concepts and providing concrete examples of this approach through interactive lawyering, client role-play, during moot court preparation and mediation lectures ${ }^{28}$ legitimise concepts such as counselling and prevention. ${ }^{29}$ Introducing the abovementioned concepts to law students from their first year allows for a change in mind-set that can result in social change and a transformed form of adjudication, as envisaged by our Constitution. ${ }^{30}$

20 When an assessor is appointed, the presiding officer must consider the cultural, social and educational background of the offender and in this framework the assessor actually acts as a "healing agent" ensuring a better outcome. Rautenbach 2005 SAJHR 324.

21 Correctional supervision negates the negative effects of confinement on all interested parties, such as the family members of the offender. Rautenbach 2005 SAJHR 323. This form of sentencing provides for a more positive impact of the law on the emotional well-being of the parties.

22 Rautenbach 2005 SAJHR 323-324.

23 See Stolle 1996 Behav Sci \& L 465; Webster and Gove Webster's Third New International Dictionary.

24 See Stolle 1996 Behav Sci \& L 466.

25 See Stolle 1996 Behav Sci \& L 466.

26 See para 9 below.

27 See for example Stolle and Wexler 1997 Preventive L Rep; Rautenbach 2005 SAJHR 323. Students can engage with the content of the article by Rautenbach as the content provides an opportunity to integrate the concept of therapeutic jurisprudence into the first year curriculum through discussions of the court structure and specifically customary courts in South Africa. The court structure and customary courts are part of the first year curriculum. Also see Stolle and Wexler 1997 Preventive L Rep 7.

28 See paras 7 and 8 below.

29 Stolle and Wexler 1997 Preventive $L$ Rep 7.

30 Also see Davies 2015 Acta Juridica 174. 


\section{The Bachelor of Laws (LLB) degree and the need to transform legal education}

The previous five-year academic LLB programme, followed by vocational training, was lengthy and expensive and, as Midgley ${ }^{31}$ says, "a luxury that South Africa could ill afford in transitional times". The four-year undergraduate law degree was introduced in $1998^{32}$ to provide access to previously disadvantaged groups in an attempt to create a broadly representative legal profession through the introduction of a cheaper and shorter degree. Unfortunately students struggled to complete the degree in just four years. Currently the major role players ${ }^{33}$ are reconsidering the LLB curriculum and the possible adding of another year to the four-year Bachelors of Laws degree. This process is not unique to South Africa. There have been changes to legal practice and higher education in countries such as Australia, Brazil, Canada, the UK, Ghana, Hong Kong, India, Nigeria and Zimbabwe. ${ }^{34}$

One of the main challenges that need to be considered when extending the degree is the matter of financial support. A large number of students currently receive funding from the state through the NSFAS (National Student Financial Aid Scheme). Currently funding is made available for only a limited period. Students have indicated that their families also need financial support and often depend on them to start earning money at the earliest opportunity to provide such support. The general unpreparedness of students entering universities as well as their lack of academic literacy and numeracy skills must also be considered.

Responses from law firms and even the Bench have indicated that the current four-year LLB degree (undergraduate) does not prepare students adequately for the legal profession. ${ }^{35}$ The problems identified include a lack of literacy skills, analytical skills, ethics, morals, and a general lack of maturity or awareness when dealing with clients. Students cannot solve problems or think critically and are unable to communicate arguments

31 Midgley "Legal Education in a Transitional Society". See also Pickett LLB Curriculum Research Report.

32 The degree was introduced by the Qualification of Legal Practitioners Amendment Act 78 of 1997.

33 The South African Law Deans' Association published a position paper proposing the five-year degree. It was based on research that indicated that only 35 per cent of all LLB students graduate within four years and only 55 per cent ever graduate at all (see Rabkin Business Day 1).

34 Dicker 2011 Advocate 22-26.

35 Pickett LLB Curriculum Research Report 26. See also Dicker 2013 Advocate 15. 
logically. A general work ethic is lacking in graduates. Legal practitioners represent the community and must have the ethics necessary to gain the confidence of the public. They need to exude a certain level of professional integrity. In addition to the skills and knowledge mentioned, universities need to deliver students that are socially conscious, strive for social justice and contribute to the constitutional imperative of access to justice. In the 2010 LLB curriculum research report, 61,3 per cent of legal academics indicated that the main aim of the programme was to develop well-rounded law graduates who are able to engage with legal concepts and can contribute to the legal profession and society. ${ }^{36}$

Judge Bosielo said the following about the legal profession in South Africa:

It is universally accepted that the strength and vitality of any constitutional democracy depends largely on the quality, pedigree and integrity of its lawyers. A weak legal profession will produce weak judges. We want to have legal professionals who believe in fairness and equality, upholding the constitutional values. We need lawyers who actually understand the constitution. Lawyers should have the spirit of ubuntu and be willing to sacrifice, instead of being selfish. They should be socially conscious and develop an ethos of batho pele and be prepared to serve the community. ${ }^{37}$

The above comments suggest the urgent need to transform legal education. By integrating therapeutic jurisprudence principles and constitutional values into the South African law curricula we can develop legal professionals that will uphold the values of the constitution, eventually producing judges that will uphold the constitutional democracy.

In 1998 Klare described a conscientious judge in the new South Africa as above all someone who would "promote and fulfill through one's professional work the democratic values of human dignity, equality and freedom and to work to establish a society based on democratic values, social justice and fundamental human rights". ${ }^{38}$ This should also be true of conscientious legal professionals, and as educators we should strive to develop law graduates that will be committed to social transformation and at the same time adhere to the norms and expectations of the profession. ${ }^{39}$ A well-rounded graduate should have the capacity to be accountable and take responsibility in an academic, professional and social context. ${ }^{40}$ The incorporation of therapeutic jurisprudence principles allows law lecturers to create an awareness of and respect for human

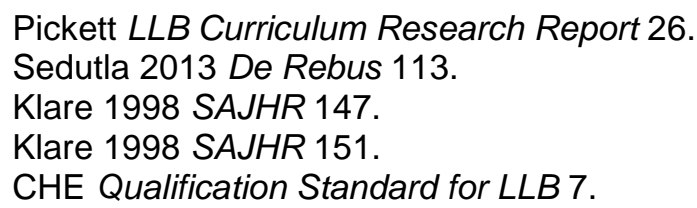


dignity, ${ }^{41}$ (both a value and a right in the constitution) by teaching students to uphold the constitutional values. Fred Zacharias suggests that we should think of therapeutic jurisprudence and preventative laws in terms of the law's effect on lawyers and law students as well as in terms of the effect on clients, litigants and other lay participants in the legal process. ${ }^{42}$

The current debate about the restructuring of the LLB degree brought role players from academia and the profession together in an attempt to answer once again the old question: Should law schools train lawyers for practice or rather pursue a broader, academic legal education? In South Africa, the social and historical context as well as the urgent need for the transformation of our legal profession must also be considered. It is not just about delivering graduates that have knowledge of the law, but rather individuals that have a deep understanding of our constitutional values and of their responsibility to safeguard these values. In addition to this, graduates should display an understanding of social life and justice. ${ }^{43}$

\section{$4 \quad$ The Legal Practice Act 28 of 2014}

The preamble to the Legal Practice Act 28 of 2014 states that it aims to provide a legislative framework for the transformation and restructuring of the legal profession into a profession which is broadly representative of South Africa's demographics, to ensure that the values underpinning the Constitution are embraced, that the rule of law is upheld, and to ensure that legal services are accessible.

The abovementioned objectives of the act highlight the responsibilities of universities to produce socially conscious graduates that strive for social justice and contribute to the constitutional imperative of access to justice. In South Africa there are 22473 attorneys; one attorney for every 2350 people. For those living in rural areas, access to these legal professionals is often difficult and expensive. ${ }^{44}$

Section 29 of the Act provides that community service may be included as a component of vocational training by candidate legal practitioners, as well as a minimum period of recurring community service by practising legal

\footnotetext{
41 In S v Makwanyane 19952 SACR 1 (CC) para 328 O' Regan held that dignity is "an acknowledgement of the intrinsic worth of human beings".

42 Zacharias 1999 Psychol Pub Pol'y \& L 913.

43 Klare 1998 SAJHR 167.

44 GroundUp 2014 http://groundup.org.za/article/getting-community-servicelawyers-right. In Australia there is approximately one attorney for every 230 people.
} 
practitioners. If a programme similar to that of medical graduates is proposed, this would certainly contribute to the constitutional imperative of access to justice for all. The continued enrolment of legal practitioners can be made dependent on this requirement. Although at this stage it is only an enabling provision, if implemented successfully it could be a cornerstone for the transformation of our future lawyers. Role players face many challenges in the successful implementation of this provision, such as a lack of resources and places for graduates to complete community service. It is a possibility that law clinics at universities may be asked to assist with this community service as a component of practical vocational training; however, the lack of resources to provide for this will be a major challenge. Community service will not only promote access to justice, but can also support a therapeutic approach, teaching the student the importance of enhancing the wellbeing of the client and the community.

\section{The role of a professional legal identity in transforming legal education}

First-year law students in South Africa face many challenges. Not only is the gap between higher and tertiary education constantly widening, but they are now exposed to a foreign discipline. Internationally law schools are recognised as the sites of a "stressful and rigorous tertiary education experience". ${ }^{45}$ Initially teaching practices did not have regard for the stressful nature of legal education or the first-year transition of law students or the mental well-being of the students during their studies. Currently at many universities in South Africa emphasis is placed on the first-year experience through extended first-year seminars to assist students with the initial transition from higher education to tertiary education and the exposure to a foreign discipline.

At the University of Johannesburg the "first-year experience" is built on the premise that every first-year student will be treated with the appropriate respect due to all citizens in South Africa. The first-year experience has been conceptualised as a holistic programme that encompasses all aspects of the first-year experience in the context of an invitational and equitable institution. It comprises both curricular and extracurricular

\footnotetext{
45. Kelk et al 2009 http://ww.cald.asn.au/docs/Law\%20Report. This study among Australian law students indicates that more than one-third experience high levels of psychological distress compared to one-sixth of medical students. Studies in American law schools have indicated high levels of depression, anxiety and even substance abuse amongst law students.
} 
initiatives. It attempts to establish an ethos and a way of life through which all first-year students will experience the transition into university life.

Students at the University of Johannesburg are supported throughout their studies by the Psychological and Career Development Services (PsyCad). ${ }^{46}$ PsyCad offers counselling to academically at risk students, psychological counselling, career guidance, strategies to prevent academic failure, strategies to manage stress, strategies in respect of time management and a 24-hour crisis line to all students. The services offered by PsyCad also focus on the emotional life and wellbeing of all students and enhance and broaden aspects of a therapeutic jurisprudence approach $^{47}$ to include a focus on the well-being of all students.

Developing a professional legal identity from the first year of studies can support the transition into university life. A professional identity is not a static concept and can be defined as a complex matrix of internalised expectations and behaviours that arise from a role or distinct network of relationships. ${ }^{48}$ Field, Duffy and Huggins state that by engaging law students with the concept of a positive professional identity, student engagement and intrinsic motivation will increase, because they are working towards a career goal that has meaning and purpose, and this contributes to addressing high levels of psychological distress. ${ }^{49}$

For a first-year law student this professional legal identity will include a "constellation of attributes, beliefs and values, motives and experiences". ${ }^{50}$ According to Stryker and Serpe a student's academic integrity becomes the highest ranking of their identities within the first months of their studies, highlighting the importance of establishing a professional identity during orientation as a first encounter with law students. ${ }^{51}$ Through this first encounter with a professional identity, law students embrace their selfconcept of the role they will play as lawyers, and the different identities of the lawyer's role in society. ${ }^{52}$ Initially this professional identity can be influenced by a number of sources such as TV images, society and the way communities perceive the role of a lawyer. To assist students to accurately engage with a legal professional identity, first-year students at the University of Johannesburg are introduced to various legal

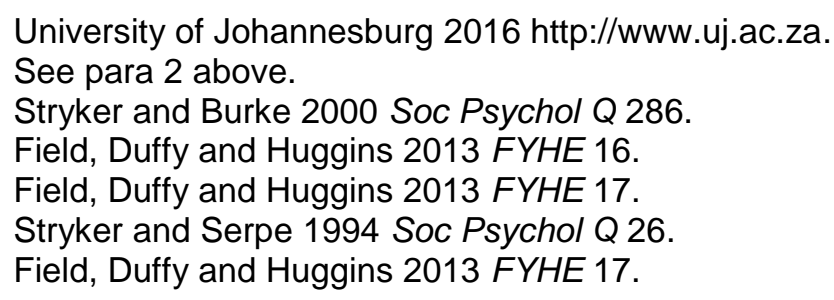


professionals during orientation. ${ }^{53}$ Judges, attorneys, prosecutors and advocates address students on their future role, the ethics of the profession, the importance of our constitutional values and the role of the law to repair. Students are then given the opportunity to engage with the various members of the profession.

In the creation of this professional legal identity, authentic learning (learning to be) plays a valuable role. When establishing this emergent professional legal identity, it is important for a law student not to experience knowledge as a mere static product of information production and consumption, but as a process and instrument of inquiry to solve problems. Whereas learning about entails the learning of subject theory, such as concepts and facts, authentic learning promotes the application of theory to analyse real-life problem situations. Students can now experience an authentic sense of who they will be as a lawyer.

To encourage authentic learning from the first year, students are provided with real-life problem situations such as mooting during formal assessments as well as in various role-play exercises and court visits. At the University of Johannesburg first-year students have the opportunity to visit three courts during the year. Of particular relevance is the guided visit to the Constitutional Court. Students can now experience South Africa's history of transformation and the importance of its Constitution, constitutional values and the Constitutional Court.

In supporting a meaningful, integrated approach to teaching, the development of these skills should be intensified during each consecutive year of study, until final-year students are exposed to practical experiences in the law clinic. Through authentic learning activities students are able to connect the activities to the real-life tasks of a legal professional. The challenge is to engage students with their learning from the first year, as engaged students achieve a higher quality of learning and then devote more time, energy and resources to the various activities. ${ }^{54}$ The engagement of students can be achieved through the use of an integrated approach, providing real-life situations relevant to the various

53 Highlighting the role of the law at this early stage introduces law students to important therapeutic jurisprudence principles whereby the role of the law is also seen as a social force and a tool to bring about transformation. At the Queensland University Technology Law School members of the profession are introduced to students during a Lawyering and Dispute Resolution module. Students are also given the opportunity to engage with these members of the profession (Field, Duffy and Huggins 2013 FYHE 21).

54 Field, Duffy and Huggins 2013 FYHE 19. 
subjects in the curriculum and by connecting with the discipline beyond the prescribed minimum learning requirements. This approach allows the student to make connections with broader concepts and experiences. ${ }^{55}$ Field, Duffy and Huggins argue that when students perceive their legal identity in a positive manner, they are informed and contextualised by a sense of purpose for their future role as professionals. ${ }^{56}$ Through engaging in an authentic learning process students will acquire a sense of personal and professional verification. ${ }^{57}$ This process also promotes the students' psychological wellbeing, once again enhancing therapeutic jurisprudence principles. When students experience the legal role in a positive manner it creates a sense of belonging to the law faculty and also the legal profession.

The authentic learning activities also provide a framework for the incorporation of therapeutic jurisprudence outcomes ${ }^{58}$ and the advancement of constitutional values. In line with the notion of transformative constitutionalism, legal education must include matters of morality, policies, politics and social issues. ${ }^{59}$ The integration of therapeutic jurisprudence throughout the law student's studies, starting at orientation and continuing through the final-year clinical experience, will enhance therapeutic outcomes for all the parties involved.

The constitutional imperative of access to justice for all underlines the importance for law teachers to incorporate therapeutic jurisprudence in their teaching methods from the first year until the completion of the students' studies. Recently the Constitutional Court led the way in ensuring that poor people also have access to justice, and awareness must be created amongst students as to the importance of access to justice in support of our constitutional values. ${ }^{60}$ Therapeutic outcomes achieved by teaching through a therapeutic lens contribute to a national goal to improve access to justice in our country.

Through the placement of students in real-life situations, including role play (lawyer/client interactions), we encourage an approach in which law

\footnotetext{
55 Field, Duffy and Huggins 2013 FYHE 19.

56 Field, Duffy and Huggins 2013 FYHE 19.

57 Field, Duffy and Huggins 2013 FYHE 18.

58 According to Stolle and Wexler therapeutic jurisprudence focuses on the law's impact on emotional life and recognises that the law itself can be seen as a therapeutic agent (Stolle and Wexler 1997 Arizona L Rev 1).

59 Quinot 2012 SALJ 411.

60 Motswagae v Rustenburg Local Municipality 20132 SA 613 (CC).
} 
and legal practice may be more humane, therapeutic, and beneficial. ${ }^{61}$ Encouraging this approach fosters the development of ubuntu, as defined by Mokgoro $\mathrm{J}$ in $S$ v Makwanyane.62

[1]t envelops the key values of group solidarity, compassion, respect, human dignity, conformity to basic norms and collective unity, in its fundamental sense it denotes humanity and morality.

\section{$6 \quad$ Letter writing and drafting skills}

Teaching letter writing skills and the value of plain language to law students creates excellent opportunities to integrate valuable therapeutic jurisprudence principles into students' learning. A therapeutic jurisprudence approach concentrates on the law's impact on the emotional life and psychological wellbeing of all the participants, ${ }^{63}$ whereas the focus in the drafting of letters and other legal documents must primarily be on the emotional wellbeing of the client. It is important to introduce the purpose and fundamentals of therapeutic jurisprudence already in the first academic year, as this cultivates an awareness of the importance of the client-lawyer relationship and contributes towards an inherent culture promoting the psychological and physical wellbeing of the people involved. 64

\subsection{Plain language}

In terms of section 64 the National Credit Act, ${ }^{65}$ the consumer has the right to information in plain and understandable language. The Act further states that a document is regarded as having been written in plain language if it is reasonable to conclude that an ordinary consumer of the class of persons for whom the document is intended, with average literacy

\footnotetext{
Diacoff "Afterword" 465.

S v Makwanyane 19952 SACR 1 (CC) para 308.

Wexler 1999 http://www.law.arizona.edu/depts/upr-intj/intj-welcome.html.

Baker and Zawid 2005 St Thomas L Rev 711.

National Credit Act 34 of 2005. Right to information in plain and understandable language, s 64. "(1) The producer of a document that is required to be delivered to a consumer in terms of this Act must provide that document (a) in the prescribed form, if any, for that document; or (b) in plain language, if no form has been prescribed for that document. (2) For the purposes of this Act, a document is in plain language if it is reasonable to conclude that an ordinary consumer of the class of persons for whom the document is intended, with average literacy skills and minimal credit experience, could be expected to understand the content, significance, and import of the document without undue effort, having regard to- (a) the context, comprehensiveness and consistency of the document; (b) the organization, form and style of the document; (c) the vocabulary, usage and sentence structure of the text; and (d) the use of any illustrations, examples, headings, or other aids to reading and understanding."
} 
skills and minimal credit experience, could be expected to understand the content, significance, and import of the document without undue effort. Section 22 of the Consumer Protection Act $^{66}$ establishes a similar condition as section 64 of the National Credit Act regarding the right to the provision of information in plain and understandable language.

Baitsewe ${ }^{67}$ suggests that external structure can be a mechanism that can aid consumers by means of descriptive headings, a table of contents, text boxes to highlight important text sections, a legible font type and size, white spacing and capital letters. ${ }^{68}$ Throughout their studies, specifically in the Legal Skills course and the module Law of Contract, students must be made aware of the needs of their clients for the information and structure that would best assist their understanding of the content of the document. ${ }^{69}$ The goal is to "empower consumers to understand the contracts they sign and to make informed decisions". ${ }^{70}$ This will definitely result in a therapeutic jurisprudence outcome for the reader of the document.

\section{$7 \quad$ Moot Court}

The benefits of mooting for students include the following: the improvement of research and writing skills as well as reading skills; the enhancement of analytical ability, and the improvement of self-confidence. It allows for reflection, provides opportunities to collaborate, and develops

66 Consumer Protection Act 68 of 2008, s 22. "(1) The producer of a notice, document or visual representation that is required, in terms of this Act or any other law, to be produced, provided or displayed to a consumer must produce, provide or display that notice, document or visual representation- (a) in the form prescribed in terms of this Act or any other legislation, if any, for that notice, document or visual representation; or (b) in plain language, if no form has been prescribed for that notice, document or visual representation. (2) For the purposes of this Act a notice, document or visual representation is in plain language if it is reasonable to conclude that an ordinary consumer of the class of persons for whom the notice, document or visual representation is intended, with average literacy skills and minimal experience as a consumer of the relevant goods or service, could be expected to understand the content, significance and import of the notice, document or visual representation without undue effort, having regard to- (a) the context, comprehensiveness and consistency of the notice, document or visual representation; (b) the organization, form and style of the notice, document or visual representation; (c) the vocabulary, usage and sentence structure of the notice, document or visual representation; and (d) the use of any illustrations, examples, headings or other aids to reading and understanding."

67 Baitsewe 2012 http://www.jutalaw.co.za/newsletter/consumer.

68 Baitsewe $2012 \mathrm{http}: / / \mathrm{www}$.jutalaw.co.za/newsletter/consumer.

69 Baitsewe 2012 http://www.jutalaw.co.za/newsletter/consumer.

70 Stoop and Chürr 2013 PER 516. 
practical skills in advocacy. ${ }^{71}$ Some authors argue that mooting does not provide an opportunity to develop ethics and values; however, if the mooting exercise is conducted through different stages, including role play, consultations and mediation, mooting can create an opportunity for the development of therapeutic jurisprudence principles and the promotion of constitutional values. ${ }^{72}$

During mooting activities students are given a real-life problem, involving a family law dispute regarding the care of a child. They are now encouraged to safeguard the emotional and psychological wellbeing of the child to ensure a therapeutic outcome. As Maxwell ${ }^{73}$ suggests, divorce lawyers should adopt a preventative/therapeutic approach by giving explicit consideration to the emotional or psychological well-being of the child. Practical strategies are discussed and students have the opportunity to consult with "clients" through different lawyer/client role-play exercises. ${ }^{74}$ In analysing and researching the problem, students are constantly reminded of the importance of our constitutional values, such as human dignity and equality. At this early stage they are alerted to the fact that good lawyering includes a preventative orientation and sensitivity to the effect of the law on the client. ${ }^{75}$ Students are also required to research across disciplines, as the research problem addresses sensitive social issues such as HIV and AIDS, drug abuse and poverty, thereby including matters of morality, policy and important social issues. This allows students to connect with the discipline by going beyond prescribed learning materials and integrating broader concepts and experiences, thereby engaging them with their emergent professional identity. Addressing issues such as HIV and AIDS within a given set of facts is a productive exercise for the development of a therapeutic jurisprudence preventative framework. ${ }^{76}$ For example, students are now confronted with a client that is HIV-positive and faces many health care issues as well as legal and social issues. In the preparation of a final moot court appearance, students are alerted to the many legal and social issues associated with HIV and AIDS, such as employment discrimination, health care costs, disability insurance, assistance from government, and alienation from families and communities.

\footnotetext{
Yule, McNamara and Thomas 2010 Legal Educ Rev 138.

Yule, McNamara and Thomas 2010 Legal Educ Rev 139.

Maxwell 1997 Rev Jur UPR 154.

Maxwell 1997 Rev Jur UPR 154. This includes discussing ways to mitigate negative effects on the children.

75 Stolle and Wexler 1997 Arizona L Rev 25.

76 Stolle et al 1997 Cal W L Rev 27.
} 
The value of a client-centred approach can be explained to students through various role play exercises providing for reconciliation with family members, employers and other members of the community. Students also have the opportunity to collaborate with fellow students and tutors, providing a framework where they must treat colleagues and peers with respect.

Mooting allows for acquiring intrinsic rewards as opposed to extrinsic rewards. ${ }^{77}$ Intrinsic rewards include enjoying and finding interest in the intellectual stimulation and analysing of the law, and achieving a level of mastery that is measured internally rather than externally. Through working collaboratively they also achieve personal growth. Extrinsic rewards refer to a preoccupation with marks and a level of prestige. ${ }^{78}$ It is of the utmost importance that legal curricula foster law students' positive visions based on intrinsic rewards, thereby influencing their future professional roles and the culture of legal practice.

When students are exposed to concepts such as therapeutic jurisprudence and preventative lawyering ${ }^{79}$ an expectation is created that upon entering the profession they will promote these concepts. A therapeutic jurisprudence approach adds a human aspect to the law and enforces the constitutional value of human dignity. Justice Cameron states that the law's role is also to repair, therefore awareness that the law can afford a means of healing and restoration must be created amongst law students. ${ }^{80}$

77 Field, Duffy and Huggins notes: "Additional potential extrinsic rewards of legal practice include financial affluence, status, and power, working for prestigious firms, titles and in the context of adversarial practice winning cases. In terms of intrinsic rewards, individuals pursuing traditional legal roles within the adversarial paradigm may identify with using one's legal skills to solve client's problems, the efficient and fair resolution of disputes, facilitating due process, advocating for and upholding individual rights and promoting the rights of the disadvantaged" (Field, Duffy and Huggins 2013 FYHE 21).

78 Field, Duffy and Huggins 2013 FYHE 21. The authors refer to this as "[h]arnessing assessment to cultivate law students' connections with the intrinsic rewards of legal education and practice".

79 Preventative law is defined as "a branch of the law that endeavours to minimize the risk of litigation or to secure more certainty as to legal rights and duties". Also see Stolle et al 1997 Cal W L Rev 16. Also see para 2 above.

80 Cameron Justice 63-64. 


\section{Mediation}

Wexler explains that from a therapeutic jurisprudence viewpoint the law itself can be a potential therapeutic agent in that legal rules, procedures and the behaviour of legal actors may produce therapeutic or antitherapeutic results. ${ }^{81}$ Therapeutic jurisprudence encourages the application of the law in a more therapeutic way. ${ }^{82}$ It is concerned with the improvement of the law and the operation thereof by searching for ways of minimising negative and promoting positive effects on the wellbeing of those affected by the law. ${ }^{83}$ One of the ways in which this objective can be reached is by introducing mediation as an alternative to court-based adjudication. Students at the University of Johannesburg are made aware of this form of alternative dispute resolution during their first year, when they study Law of Persons and the Family as a subject, ${ }^{84}$ and a mediation module has been introduced into the first year Legal Skills course. Through this module students are exposed to a variety of legal rules and instruction in alternative dispute resolution. Non-adversarial justice enhances a positive legal identity for those students who prefer collaboration to argumentation. ${ }^{85}$

Currently, Western-style divorce and family mediation is practised to give effect to the Children's Act. ${ }^{86}$ According to Boniface, there is room for African group-style mediation in the context of the mediation provided for by the Children's Act. ${ }^{87}$ This mediation is facilitated by elders and takes

81 Wexler 1992 Law \& Hum Behav 27.

82 Wexler 1999 http://www.law.arizona.edu/depts/upr-intj/intj-menu.html.

83 King Non-adversarial Justice 26.

84 The Children's Act 38 of 2005 makes provision for compulsory mediation in certain instances. S 21(3)(a) determines that when the parental responsibilities and rights of unmarried fathers are in dispute, it is compulsory that the matter be referred for mediation. However, if one of the parties feels that it is in the best interest of the child, they can approach the High Court without having to engage in mediation first. With regard to parenting plans, the Act states that if co-holders of parental rights and responsibilities are having difficulties in exercising these rights, they must seek mediation, in order to agree on a parenting plan. In order to achieve this, the parties must partake in mediation through a social worker or any other qualified person.

85 Field, Duffy and Huggins 2013 FYHE 20. At the Queensland University of Technology Law School students are introduced to alternative dispute resolution by lawyering and a dispute resolution module. This module helps students to identify a mode of practice for which they feel a sense of affinity and connection.

86 Children's Act 38 of 2005. Boniface 2012 PER 379.

87 Boniface 2012 PER 393. 
place in "an attitude of togetherness" and "in the spirit of ubuntu". ${ }^{88}$ Section 71(1) states that if circumstances permit, the Children's Court may refer a matter brought before the court to any appropriate lay forum. The lay forum may include a traditional authority. The purpose is to attempt to settle the matter out of court by way of mediation. The South African Law Reform Commission hereby attempts to identify various protective mechanisms for children at risk and recognises that the extended family, friends and community form support systems for these children. ${ }^{89}$ In these communities, the values of ubuntu are exercised..$^{90}$ If these values are exercised during the mediation, it is likely that a therapeutic outcome will be achieved.

Students are also alerted to African group-style mediation and its place in the context of the Children's Act, ${ }^{91}$ as well as to the importance of ubuntu in this regard. Through role play the therapeutic jurisprudence outcomes and the constitutional values of ubuntu and human dignity will once again be highlighted. This approach will ensure that awareness of constitutional values is created from the first year of the student's legal studies.

\title{
9 Clinical legal education
}

Cronjé and Heaton ${ }^{92}$ state that

\begin{abstract}
[t]he majority of the population does not have access to private legal practitioners, as they simply cannot afford to pay lawyers' fees. Some people are able to obtain legal advice (and sometimes legal representation) through the Legal Aid Board, legal aid clinics at universities or legal advice centres of non-governmental organizations.
\end{abstract}

The University of Johannesburg has a law clinic with branches on three campuses. All final-year LLB students are required to pass the module Applied Legal Studies, of which the law clinic forms part. The law clinic is a form of service learning based in an authentic learning environment. It entails teaching and learning that is directed at specific community needs and integrated into a credit-bearing academic programme and curriculum in which students participate in contextualised, well-structured and

88 Boniface 2012 PER 381.

89 Gallinetti "Children's Court" 4-38.

90 According to Goldberg 1998 TSAR 748 another mediation model is used in Canada and the United States, apparently with partial success. It is called the sensitise-a-mediator model, in which existing conflict resolvers such as mediators are trained in cultural issues and considerations that are important to the communities served.

91 Children's Act 38 of 2005.

92 Cronjé and Heaton South African Family Law. 
organised service activities. These activities are aimed at addressing identified service needs in a community. The student must reflect on these experiences in order to gain a deeper understanding of the linkage between curriculum content and community dynamics as well as to achieve personal growth and a sense of social and civic responsibilities. ${ }^{93}$

The law clinic is managed by a director, who is a qualified and admitted attorney, and who also lectures in the subject Applied Legal Studies. In addition there are three principal attorneys (clinicians) who are assisted by a further two attorneys. Clients that qualify for representation must comply with the means test of the Law Clinic of Johannesburg. ${ }^{94}$ Students are exposed to authentic learning by being given real-life tasks in an environment where tangible results are achieved. ${ }^{95}$ Community engagement, where students render legal assistance to real live clients, who are facing actual legal problems, is a useful tool that instils in a student permanent learning of insightful knowledge of the law. ${ }^{96}$ The service learning experience has a therapeutic outcome in that it is a collaborative partnership that enhances mutual reciprocal teaching and learning among all members of the partnership. This includes lecturers, clinicians and students, members of the various communities served by the clinic, and representatives of the service sector.

Common problems identified in communities served by the law clinics at the University of Johannesburg are the following: members of the communities lack understanding and awareness of ante-nuptial contracts, and are unfamiliar with estate planning and the drafting of wills, as well as with their legal rights during eviction proceedings. Students can provide members of the community, through preventative law counselling, with the necessary information. In line with the focus of preventative lawyering, students now act as planners, counsellors and negotiators. ${ }^{97}$ Those exposed to this approach may, once in actual practice, continue performing preventative lawyering and incorporate aspects of therapeutic jurisprudence into their practice. This approach supports lawyering with an ethic of care, and will assist in producing graduates who embrace the spirit of ubuntu, are socially conscious, and are prepared to serve the community. A willingness to serve our communities must be cultivated

93 UJ Work Integrated Learning 7.

94 This test requires that a maximum of R2 500 for a single applicant or R3 500 for a household should remain once the total expenses have been subtracted from the income.

95 O'Brien Faculty of Law Year Report 2013.

96 O'Brien Faculty of Law Year Report 2013.

97 See Stolle 1996 Behav Sci \& L 466. 
amongst our students, as opposed to inducing them to pursue interests based on self-enrichment. ${ }^{98}$ The expanding notion of ubuntu as a value plays an important role in a country still endeavouring to adjust to a changing social order. ${ }^{99}$

However, to succeed in this way, students must be introduced to these approaches from the first year. A course in legal skills can provide such an opportunity through the introduction of mediation as an alternative dispute resolution method. Through the initiation of community outreach programmes at the start of the first year and following them through in the following years of studies, lecturers can provide a framework for the development of social consciousness, particularly with reference to poor and vulnerable members of society.

\section{Conclusion}

As law lecturers in South Africa we want to prepare students for an active citizenship role in society and have them display the constitutional values of human dignity, equality, freedom and ubuntu when they interact with their fellow students, lecturers, other citizens, and one day with their clients when they enter the profession. It is imperative that our students uphold guiding values such as integrity, respect for diversity and human dignity. If we consider the concept of therapeutic jurisprudence and its focus on the law's impact on emotional life and wellbeing as well as the perspective of the law's role as a social force, the similarities with our own constitutional values are clear. The incorporation of therapeutic jurisprudence principles into the curriculum would thus support and enhance the values of the Constitution. If we accept Judge Bosielo's words that the strength and vitality of any constitutional democracy depend on the quality and integrity of its lawyers, it is imperative that our students uphold these guiding values. By embodying these values they can improve the legal system, shape our legal order and promote progress toward an equal and free democratic society as envisaged by the Constitution.

\footnotetext{
98 Dicker 2013 Advocate 15.

99 Bennet 2011 PER 47.
} 


\section{Bibliography}

\section{Literature}

Baitsewe 2012 Consumer Law Review

Baitsewe R "Plain Language: More Than Just 'Plain' Words" 2012 Consumer Law Review

Baker and Zawid 2005 St Thomas L Rev

Baker $\mathrm{G}$ and Zawid $\mathrm{J}$ "The Birth of a Therapeutic Courts Externship Program: Hard Labour but Worth the Effort" 2012 St Thomas L Rev 711743

Bennet 2011 PER

Bennet TW "Ubuntu: An African Equity" 2011 PER 30-61

Boniface 2012 PER

Boniface AE "African-style Mediation and Western-style Divorce and Family Mediation: Reflections for the South African Context" 2012 PER 378-401

Cameron Justice

Cameron E Justice: A Personal Account (Tafelberg Cape Town 2014)

CHE Qualification Standard for LLB

Council on Higher Education Higher Education Qualifications SubFramework - Qualification Standard for Bachelor of Laws (LLB) (Council on Higher Education Pretoria 2015)

Cronjé and Heaton South African Family Law

Cronjé $\mathrm{D}$ and Heaton $\mathrm{J}$ South African Family Law $2^{\text {nd }}$ ed (LexisNexis Durban 2004)

Davies 2015 Acta Juridica

Davies D "Legal Transformation and Legal Education: Congruence or Conflict" 2015 Acta Juridica 172-188

Diacoff "Afterword"

Diacoff S "Afterword: The Role of Therapeutic Jurisprudence Within the Comprehensive Law Movement" in Stolle DP, Wexler DB and Winick J (eds) Practicing Therapeutic Jurisprudence: Law as a Helping Profession (Carolina Academic Press Durham 2000) 465-525

Dicker 2011 Advocate 
Dicker L "The Future of the Four Year LLB" 2011 Advocate 22-26

Dicker 2013 Advocate

Dicker L "The 2013 LLB Summit" 2013 Advocate 15

Field, Duffy and Huggins 2013 FYHE

Field R, Duffy $\mathrm{J}$ and Huggins A "Supporting Transition to Law School and Student Well-Being: The Role of a Professional Legal Identity" 2013 4(2) FYHE 15-25

Gallinetti "Children's Court"

Gallinetti J "The Children's Court" in Davel CJ and Skelton A (eds) Commentary on the Children's Act (Juta Cape Town 2007) 4-38

Goldberg 1998 TSAR

Goldberg V "Practical and Ethical Concerns in Alternative Dispute Resolution in General and Family and Divorce Mediation in Particular" 1998 TSAR 748-760

Greenbaum "Re-visioning Legal Education"

Greenbaum L "Re-visioning Legal Education in South Africa: Harmonising the Aspirations of Transformative Constitutionalism with the Challenges of our Educational Legacy" Unpublished contribution delivered at Twenty Years of South African Constitutionalism (14-16 November 2014 New York)

King Non-adversarial Justice

King M Non-adversarial Justice (Federation Press Annandale 2009)

Klare 1998 SAJHR

Klare K "Legal Culture and Transformative Constitutionalism" 1998 SAJHR 146-188

Langa 2006 Stell LR

Langa P "Transformative Constitutionalism" 2006 Stell LR 351-360

Maxwell 1997 Rev Jur UPR

Maxwell KE "Preventative Lawyering Strategies to Mitigate the Detrimental Effects of a Client's Divorces on their Children" 1997 Rev Jur UPR 135162

Midgley "Legal Education in a Transitional Society" Midgley R "South Africa: Legal Education in a Transitional Society" Paper presented at the Law and Society Association (2008 Berlin) 
O'Brien Faculty of Law Year Report 2013

O'Brien P University of Johannesburg Faculty of Law Year Report 2013 (UJ Johannesburg 2013)

Pickett LLB Curriculum Research Report

Pickett G The LLB Curriculum Research Report. A Research Report Produced for the Advice and Monitoring Directorate of the Council on Higher Education (November) (The Council Pretoria 2010)

Quinot 2012 SALJ

Quinot G "Transformative Legal Education" 2012 SALJ 411-433

Rabkin Business Day

Rabkin F "Ill-equipped Law Graduates not Ready for Practice" Business Day (16 January 2014) 1

Rautenbach 2005 SAJHR

Rautenbach C "Therapeutic Jurisprudence in the Customary Courts of South Africa: Traditional Authority Courts as a Therapeutic Agent" 2005 SAJHR 323-335

Sedutla 2013 De Rebus

Sedutla M "LLB Summit: Legal Education in Crisis" 2013 De Rebus 113118

Stolle 1996 Behav Sci \& L

Stolle D "Professional Responsibility in the Elder Law: A Synthesis of Preventative Law and Therapeutic Jurisprudence" 1996 Behav Sci \& L 459-478

Stolle and Wexler 1997 Arizona $L$ Rev

Stolle D and Wexler D "Therapeutic Jurisprudence and Preventative Law: A Combined Concentration to Invigorate the Everyday Practice of Law" 1997 Arizona L Rev 1-39

Stolle and Wexler 1997 Preventive L Rep

Stolle D and Wexler D "Preventative Law and Therapeutic Jurisprudence: A Symbolic Relationship" 1997 Preventive L Rep 4-8

Stolle et al 1997 Cal W L Rev

Stolle $\mathrm{D}$ et al "Integrating Preventative Law and Therapeutic Jurisprudence: a Law and Psychology Based Approach to Lawyering" 1997 Cal W L Rev 15-54 
Stoop and Chürr 2013 PER

Stoop PN and Chürr $C$ "Unpacking the Right and Understandable Language in the Consumer Protection Act 68 of 2008" 2013 PER 515-614 Stryker and Burke 2000 Soc Psychol Q

Stryker $S$ and Burke $P$ "The Past, Present and Future of an Identity Theory" 2000 Soc Psychol Q 284-297

Stryker and Serpe 1994 Soc Psychol Q

Stryker S and Serpe R "Identity Salience and Psychological Centrality: Equivalent, Overlapping or Complimentary Concepts?" 1994 Soc Psychol Q 16-35

\section{UJ Work Integrated Learning}

University of Johannesburg Work Integrated Learning and Service Learning Policy Drafted by Academic Development and Support, Approved on 17 July 2007 (UJ Johannesburg 2007)

Webster and Gove Webster's Third New International Dictionary

Webster N and Gove PB Webster's Third New International Dictionary of the English Language (Bell London 1961)

Wexler 1992 Law \& Hum Behav

Wexler DB "Putting Mental Health into Mental Health Law: Therapeutic Jurisprudence" 1992 Law \& Hum Behav 27-38

Yule, McNamara and Thomas 2010 Legal Educ Rev

Yule J, McNamara $\mathrm{J}$ and Thomas $\mathrm{M}$ "Mooting and Technology: To what Extent does Using Technology Improve the Mooting Experience for Students" 2010 Legal Educ Rev 137-153

Zacharias 1999 Psychol Pub Pol'y \& L

Zacharias FC "Professional Responsibility, Therapeutic Jurisprudence and Preventative Law" 1999 Psychol Pub Pol'y \& L 909-920

\section{Case law}

S v Makwanyane 19952 SACR 1 (CC)

Motswagae v Rustenburg Local Municipality 20132 SA 613 (CC)

\section{Legislation}

Children's Act 38 of 2005 
Constitution of the Republic of South Africa, 1996

Consumer Protection Act 68 of 2008

Legal Practice Act 28 of 2014

National Credit Act 34 of 2005

Qualification of Legal Practitioners Amendment Act 78 of 1997

Internet sources

Baitsewe 2012 http://jutalaw.co.za/newsletter/consumer

Baitsewe R 2012 Plain Language: More Than Just 'Plain' Words http://www.jutalaw.co.za/newsletter/consumer accessed 10 February 2016

GroundUp 2014 http://groundup.org.za/article/getting-community-servicelawyers-right

GroundUp 2014 Getting Community Service for Lawyers Right http://groundup.org.za/article/getting-community-service-lawyers-right accessed 20 October 2014

Kelk et al 2009 http://ww.cald.asn.au/docs/Law\%20Report

Kelk N et al 2009 Courting the Blues: Attitudes towards Depression in Australian Law Students and Lawyers http://ww.cald.asn.au/docs/ Law\%20Report accessed 10 May 2015

University of Johannesburg 2016 http://www.uj.ac.za

University of Johannesburg 2016 Home Page http://www.uj.ac.za accessed 13 April 2016

Wexler 1999 http://www.law.arizona.edu/depts/upr-intj/intj-welcome.html Wexler D 1999 International Network on Therapeutic Jurisprudence http://www.law.arizona.edu/depts/upr-intj/intj-welcome.html accessed 15 June 2015

\section{List of Abbreviations}

$\begin{array}{ll}\text { Arizona L Rev } & \text { Arizona Law Review } \\ \text { Behav Sci \& L } & \text { Behavioral Sciences and the Law } \\ \text { Cal W L Rev } & \text { California Western Law Review } \\ \text { Cath U L Rev } & \text { Catholic University Law Review } \\ \text { CHE } & \text { Council on Higher Education } \\ \text { FYHE } & \text { International Journal of the First Year in Higher }\end{array}$




$\begin{array}{ll} & \text { Education } \\ \text { Law \& Hum Behav } & \text { Law and Human Behavior } \\ \text { Legal Educ Rev } & \text { Legal Education Review } \\ \text { LLB } & \text { Bachelor of Laws } \\ \text { NSFAS } & \text { National Student Financial Aid Scheme } \\ \text { PER } & \text { Potchefstroom Elektroniese Regstydskrif } \\ \text { Preventive L Rep } & \text { Preventive Law Reporter } \\ \text { PsyCad } & \text { Psychological and Career Development Services } \\ \text { Psychol Pub Pol'y \& L } & \text { Psychology, Public Policy and Law } \\ \text { Rev Jur UPR } & \text { Revista Juridica Universidad de Puerto Rico } \\ \text { SAJHR } & \text { South African Journal on Human Rights } \\ \text { SALJ } & \text { South African Law Journal } \\ \text { Soc Psychol Q } & \text { Social Psychology Quarterly } \\ \text { St Thomas L Rev } & \text { St Thomas Law Review } \\ \text { Stell LR } & \text { Stellenbosch Law Review } \\ \text { TSAR } & \text { Tydskrif vir die Suid-Afrikaanse Reg } \\ \text { UJ } & \text { University of Johannesburg }\end{array}$

